\title{
UTICAJNI FAKTORI NA IZBOR PODRUČJA POGODNIH ZA GRADNJU ŠUMSKIH KAMIONSKIH PUTEVA
}

\author{
Significant factors in determining forest areas suitable for forest roads \\ construction
}

\author{
Dževada Sokolović ${ }^{1}$, Ahmet Lojo ${ }^{1}$, Muhamed Bajrić ${ }^{1}$, Velid Halilović ${ }^{1}$
}

\begin{abstract}
For rational forest management and realization of the bio-technical planed activities on time it is inevitable to build widely branched network of forest roads of sufficient density. Simultaneously with this it is necessary to take into consideration that roads are not only significant for production aspect of forest but also for many other aspects: ecological, sociological, environmental etc. The best solution for forest opening is achieving the best possible forest accessibility with lowest possible investment. The targeted result in forest opening is optimum forest roads network. Optimization of forest roads network is achievable by mathematical formula of minimizing total costs. Methods for optimization of forest roads network by means of computers analyze numerous factors and have different approach to resolving forest opening.

In this paper the analysis has been done in order to get areas suitable for construction of forest truck roads. Influence factors taken into account for analysis areas follows: normal stock, depth of the soil and terrain slope. After evaluation of areas which are more or less suitable for forest truck roads for each specific influence factor it has been got aggregate thematic map in which areas suitable and non suitable for construction of forest truck roads have been given.
\end{abstract}

Key words: forest truck roads, forest opening.

\section{Izvod}

Za racionalno gazdovanje šumama i pravovremeno provođenje svih planiranih biotehničkih mjera, neophodno je izgraditi dovoljno gustu i razgranatu mrežu šumskih saobraćajnica. Pri tome se ima u vidu da putevi nemaju značaj samo za proizvodni aspekt šume, već i za sve ostale mnogobrojne aspekte: ekološki, sociološki, zaštitni itd. Najbolje rješenje u otvaranju šuma jeste kada se postigne da se sa što manje uloženih sredstava dobije što bolje otvorena šuma. Rezultat kojem se teži u otvaranju šuma jeste optimalna mreža šumskih saobraćajnica. Optimalizaciju mreže šumskih

\footnotetext{
${ }^{1}$ Šumarski fakultet Univerziteta u Sarajevu - Faculty of Forestry University of Sarajevo
} 
saobraćajnica je moguće uraditi pomoću matematičke formule minimiziranjem ukupnih troškova. Metode koje optimalizaciju mreže šumskih saobraćajnica rade pomoću računara, analiziraju veći broj faktora i imaju različit pristup u rješavanju otvaranja.

U ovom radu je izvršena analiza na osnovu koje su se dobila područja pogodna za gradnju šumskih kamionskih puteva. Uticajni faktori koji su se uzeli za analizu su: normalna zaliha, dubina zemljišta i nagib terena. Nakon bodovanja područja, koja su za svaki od uticajnih faktora ponaosob manje ili više pogodna za gradnju šumskih kamionskih puteva, dobila se zbirna tematska karta. Na njoj su izdvojena područja koja su pogodna i područja koja nisu pogodna za gradnju šumskih kamionskih puteva.

Ključne riječi: šumski kamionski putevi, otvaranje šuma.

\section{Uvod - Introduction}

Nedovoljna otvorenost šuma ima za posljedicu nepravilan raspored drvnih masa dostupnih za sječu. U nedovoljno otvorenim šumama sječe se intenzivno vrše na područjima oko šumskih saobraćajnica te se na taj način, često stanje zalihe drvne mase dovodi do granice devastacije. U neotvorenim šumskim područjima dolazi do propadanja drvne mase prezrelih stabala jer bi njihovo privlačenje bilo skupo i neekonomično, i nemogu se provoditi adekvatne mjere njege šumskih sastojina. Tako da te šumske površine stvarno nisu uključene u šumarsku proizvodnju, i ne učestvuju u formiranju prihoda.

Jedan od najznačajnijih razloga slabe otvorenosti šuma jesu visoki troškovi gradnje šumskih kamionskih puteva. Oni se u zavisnosti od obima zemljanih radova i kategorije terena kreću između $70000-200000 \mathrm{KM} / \mathrm{km}$. Zbog ovako visokih troškova gradnje, kao i zbog velikog značaja šumskih saobraćajnica za gazdovanje šumama, otvaranje šuma se mora raditi planski i studiozno. Cilj koji se postavlja kod otvaranja šuma jeste optimalna mreža šumskih saobraćajnica. S obzirom da se svako šumsko područje karakteriše posebnostima u pogledu sastojinskih i terenskih uslova, za svako šumsko područje potrebno je uraditi poseban i jedinstven plan otvaranja.

Za određivanje optimalne mreže šumskih saobraćajnica postoje mnogobrojne metode. Metode koje optimalizaciju mreže šumskih saobraćajnica rade pomoću matematičke formule su istorijski posmatrano ranije nastale. Metode novijeg datuma optimalizaciju mreže šumskih saobraćajnica rješavaju pomoću računara. Analiza otvaranja šuma pomoću računara pruža mogućnost sagledavanja velikog broja faktora. Pri tome određene faktore je moguće grupisati i analizirati u zasebnim nivoima prema potrebnom i logičnom slijedu. Tako, na primjer, prije davanja idejnih trasa šumskih saobraćajnica potrebno je analizirati grupu faktora koja utiče na izbor šumskih područja pogodnih za gradnju šumskih kamionskih puteva. U ovom radu je urađena analiza u cilju definisanja područja pogodnih za gradnju šumskih kamionskih 
puteva. Ona može predstavljati dobru osnovu za dalje otvaranje analiziranog šumskog područja i može se nazvati prvim nivoom optimalizacije.

\section{Problematika istraživanja -Scope of research}

\section{Određivanje optimalne otvorenosti - Determine the optimum openness}

Za optimalizaciju mreže šumskih kamionskih puteva potrebno je raspolagati slijedećim relevantnim podacima: vrsta sastojine, geološka podloga, drvna zaliha, etat. Potrebno je utvrditi koliki su troškovi gradnje, održavanja, transporta drvne mase itd.

Poznate su mnogobrojne metode i kriteriji za optimalizaciju mreže šumskih saobraćajnica, od kojih su neke u nastavku izdvojene i opisane.

KLEMENČıć (1939) pod optimalnom gustoćom mreže šumskih puteva podrazumijeva onu kod koje su ukupni troškovi otpreme minimalni. Za računanje troškova otpreme daje obrazac:

$T_{o}=T_{i z}+\left(T_{g}+T_{t}\right)$;

gdje je:

$\mathrm{T}_{\mathrm{o}}$-troškovi otpreme

$\mathrm{T}_{\mathrm{iz}}$-troškovi izvlačenja

$\mathrm{T}_{\mathrm{g}}$ - troškovi gradnje

$\mathrm{T}_{\mathrm{t}}$ - troškovi transporta

POPOVIĆ i NiKolIĆ (1968) upoređivanjem troškova transporta drveta kamionskim putem i troškova transporta drveta traktorskim vlakama, određuju minimalne troškove transporta drvnih sortimenata i na osnovu toga određuju koliku dužinu puta treba izgraditi za kamionski saobraćaj a koliku dužinu puta kao traktorski put ili traktorsku vlaku.

$\mathrm{T}_{\min }=\mathrm{T}_{\mathrm{ik}}+\mathrm{T}_{\mathrm{ok}}+\mathrm{T}_{\mathrm{iv}}+\mathrm{T}_{\mathrm{ov}}+\mathrm{T}_{\mathrm{p}}+\mathrm{T}_{\mathrm{v}}+\mathrm{T}_{\mathrm{s}}$

gdje je:

$\mathrm{T}_{\mathrm{ik}}$ - troškovi izgradnje kamionskog puta

$\mathrm{T}_{\mathrm{ok}}$ - troškovi održavanja kamionskog puta

$\mathrm{T}_{\mathrm{iv}}$ - troškovi izgradnje traktorskog puta ili vlake

$\mathrm{T}_{\mathrm{p}}$ - troškovi transporta drveta po kamionskom putu

$\mathrm{T}_{\mathrm{v}}$ - troškovi transporta drveta po traktorskom putu

$\mathrm{T}_{\mathrm{s}}$ - troškovi transporta drveta od panja do traktorske vlake

JELIČIĆ (1969) kao osnovne troškove za određivanje optimalne mreže šumskih kamionskih puteva uzima: troškove privlačenja i prevoza drvnih sortimenata i troškove gradnje i održavanja šumskih puteva. Za optimalni razmak između šumskih puteva daje obrazac: 
$e=\sqrt{\frac{F}{m \cdot a \cdot p_{0}} \cdot m \cdot b \cdot v_{0}+\frac{g}{f}+o} ;$

gdje je:

e- optimalni razmak između šumskih puteva (m)

F- površina od 1 ha

$\mathrm{M}$ - neto drvna masa za transport $\mathrm{u}$ t/ha

a -koeficijent privlačenja

$\mathrm{p}_{0}$ - troškovi privlačenja drveta (KM/t za $1 \mathrm{~m}$ dužni vlake)

$\mathrm{b}$ - faktor promjenljive udaljenosti težišta drvnih masa koncentrisanih pored puta

$\mathrm{v}_{0}$ - troškovi vožnje (KM/t za $1 \mathrm{~m}$ puta)

$\mathrm{g}$ - troškovi gradnje po $1 \mathrm{~m}$ puta

$\mathrm{f}$ - rentni faktor (godišnji anuitet)

o - godišnji troškovi održavanja puta po $1 \mathrm{~m}$

BOJANIN (1983) za računanje optimalnog razmaka šumskih puteva daje formulu:

$x=200 \cdot \sqrt{\frac{R}{v \cdot f \cdot Q}} ;$

gdje je:

$\mathrm{x}$ - razmak šumskih puteva $(\mathrm{m})$

$\mathrm{R}$ - troškovi gradnje i održavanja šumskih puteva $(\mathrm{KM} / \mathrm{m})$

$\mathrm{v}$ - troškovi privlačenja drveta $\left(\mathrm{KM} / \mathrm{m}^{3}\right)$

$\mathrm{Q}$ - sječiva drvna masa $\mathrm{m}^{3} / \mathrm{ha}$

$\mathrm{f}$ - faktor terena

PIČMAN (1993) na digitaliziranim šumsko-gospodarskim topografskim kartama simulira više varijanti mreže šumskih kamionskih puteva, te na kraju bira najpovoljniju varijantu za računanje optimalne otvorenosti GJ „Bistranska gora“ u Hrvatskoj.

SHIBA (1992) za određivanje optimalnog položaja šumskih kamionskih puteva pri otvaranju šuma uzima veliki broj uticajnih faktora, a kao ulazne podatke koristi aerofoto snimke i različite tematske karte kreirane pomoću GIS-a.

TAN (1992) pomoću GIS-a planira mrežu šumskih kamionskih puteva. Autor daje algoritam za analizu transporta izvan šumskih kamionskih puteva, za analizu transporta drveta po putevima, te za dizajn samog kamionskog puta. Takođe je kreiran algoritam koji određuje položaj šumskih kamionskih puteva. Kreirani model je praktično prikazan u šumskom okrugu Ylikemi u Finskoj.

KRČ (1995) koristi GIS softver za izradu modela transporta drvne mase u GJ „Jezersko“ u Sloveniji. Za podloge je koristio topografske karte sa osnovnim nosiocima informacija veličine 0,25 ha. Uticajni faktori pri izboru sredstva rada i smjera pri privlačenju drveta su: nagib terena, udaljenost nosioca informacija od šumskog kamionskog puta, smjer privlačenja drveta, kamenitost podloge, razvedenost i tvrdoća terena te dubina zemljišta. 
ERDAS, ACAR, KARAMAN \& GÜMÜS (1997) koriste GIS za izbor najboljih trasa šumskih kamionskih puteva u jednoj gospodarskoj jedinici u Turskoj. Osnovni faktori koji utiču na odabir lokacija budućih šumskih kamionskih puteva su: nagib terena, ekspozicija, zaliha drveta, vodotoci i stjenovitost područja.

PENTEK (2002) za određivanje optimalne mreže šumskih puteva uzima u obzir slijedeće fakore:

- ekonomske: građevinsku pogodnost zemljišta, nagib terena, postojeću mrežu saobraćajnica, hidrografsku mrežu;

- tehničko-tehnološke: namjenu šuma i šumskog zemljišta, vlasništvo šume, kvalitet etata, korištenu tehnologiju i sredstva rada.

Ova dva faktora su uzeta $u$ analizu u prvom prioritetnom nivou optimalizacije. U drugom prioritetnom nivou optimalizacije autor analizira uticaj slijedećih faktora:

- okolišno-ekoloških: zaštitna područja i objekti, zaštićena područja i krajolici, opasnost od šumskog požara;

- socioloških: pristup selima i zaseocima, pristup gospodarskim objektima, pristup lovačkim kućama i vikendicama, pristup turističkim i rekreacionim objektima.

ARUGA, TASAKA, SESSIONS \& MIYATA (2006) pomoću kompjuterskog programa analiziraju izbor najpovoljnije trase šumskog kamionskog puta u horizontalnom i vertikalnom smislu. U radu je testiran kompjuterski program koji ima mogućnost da crta poprečne profile, računa obim zemljanih radova i daje ukupnu procjenu troškova izgradnje i kasnijeg održavanja za različite varijante šumskih kamionskih puteva. Konačno minimiziranjem ukupnih troškova bira se najpovoljnija trasa šumskog kamionskog puta.

\section{Metode rada - Researcs methods}

Analiza će se uraditi pomoću savremenih GIS metoda i tehnologija, pri čemu će biti korišten softver WinGis 2003. koji imaju mogućnost analiziranja informacija iz integralno povezanih baza podataka, a koje imaju svoje mjesto u vremenu i prostoru. Osnovna prednost GIS-a je omogućavanje složenih analiza preklapanjem različitih tematskih karata. Ukupna otvorenost analizirane površine će se izračunati pomoću matematičke formule: $O=\frac{D}{A}$;

gdje je:

O - ukupna otvorenost analizirane šumske površine, $\mathrm{m} / \mathrm{ha}$

D - ukupna dužina puteva koji otvaraju analiziranu površinu, $m$

A - ukupna analizirana površina, ha

Za računanje otvorenosti šumske površine uzet će se u obzir slijedeći putevi (prema ŠIKIĆ i drugi, 1989): 
- put koji prolazi kroz šumu uzimat će se u obračun sa cijelom dužinom;

- put koji prolazi rubom šume ili na udaljenosti do $300 \mathrm{~m}$ od ruba i moguć je utovar na njega, u obračun će ući sa 50 \% svoje dužine;

- put koji okomito dolazi do ruba šume i tu završava, u obračun će se uzimati sa dužinom od $500 \mathrm{~m}$.

\section{Rezultati istraživanja - Research results 4.1. Opći podaci za GJ "Plješevica" - Researcs area}

Analiza je urađena na području GJ "Plješevica", koja se se nalazi unutar ŠPP “Unsko”. Ukupna površina GJ „Plješevica“ je 7554,4 ha i data je na slici 1. Za analizu su uzeti odjeli 17-76, sa ukupnom površinom od 5853,2 ha i u daljem radu će se izabrana površina za analizu otvorenosti nazivati GJ "Plješevica".

Ukupna dužina šumskih kamionskih puteva u GJ „Plješevica“ iznosi $53401 \mathrm{~m}$ (slika 2). Sadašnja otvorenost GJ „Plješevica“ je izračunata pomoću obrasca:

$O_{S}=\frac{D_{S}}{A}=\frac{53401}{5853,2}=9,12 \mathrm{~m} / \mathrm{ha}$;

gdje je:

$\mathrm{O}_{\mathrm{S}}$ - sadašnja otvorenost šume, $\mathrm{m} / \mathrm{ha}$

$\mathrm{D}_{\mathrm{S}}-$ ukupna dužina šumskih kamionskih puteva u gospodarskoj jedinici, $\mathrm{m}$

A - ukupna površina gospodarske jedinice, ha

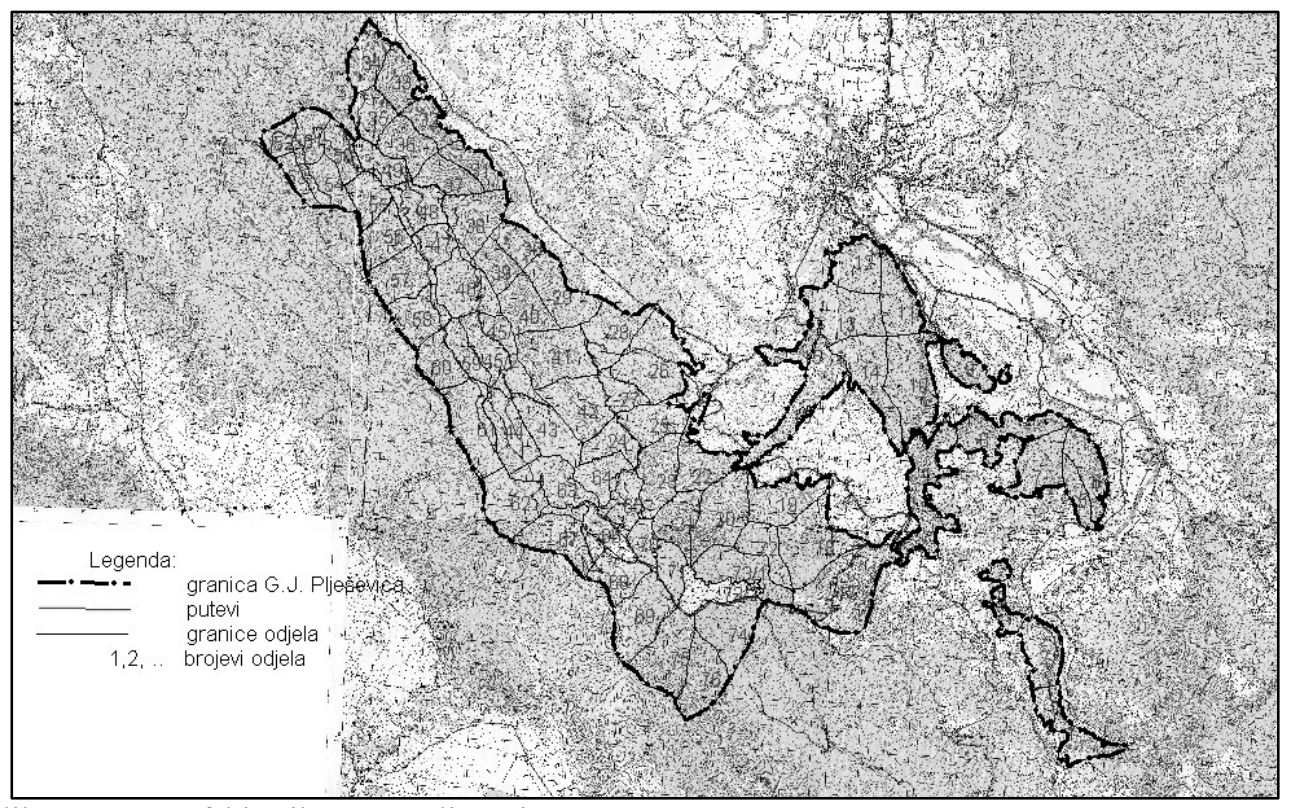

Slika 1. Geografski prikaz GJ „Plješevica“

Figure 1 Display geographically GJ "Plješevica" 


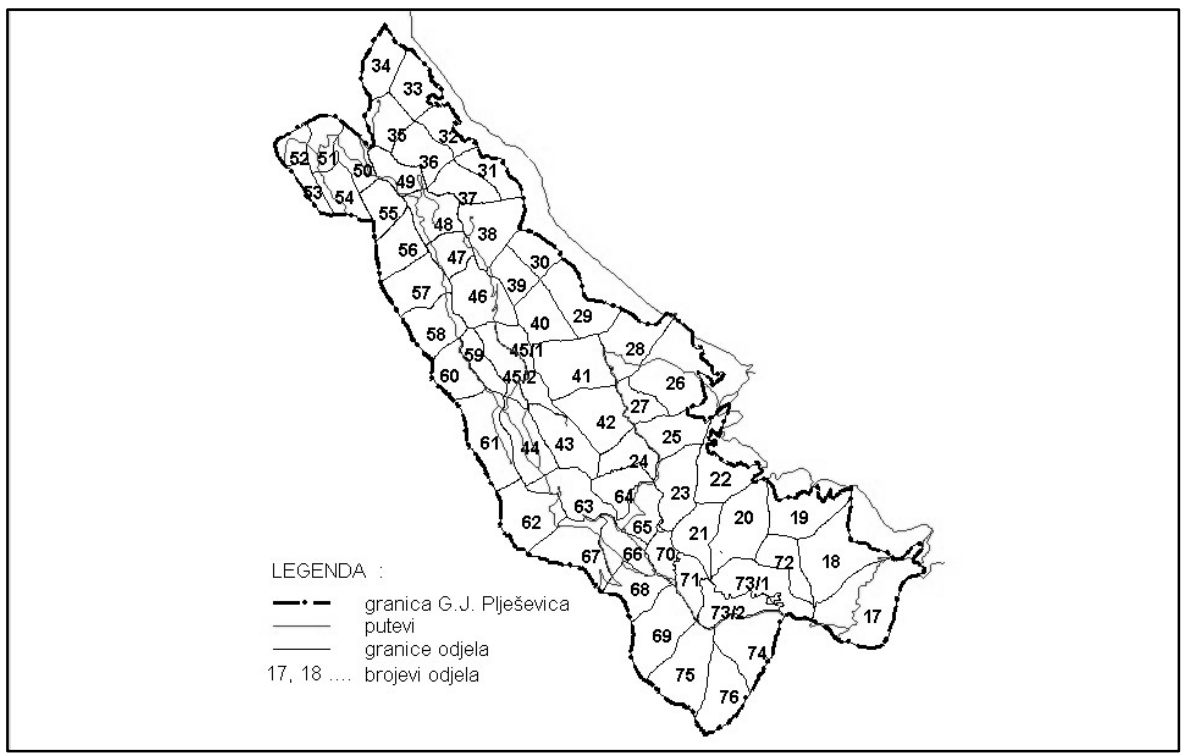

Slika 2. Postojeća mreža šumskih kamionskih puteva u GJ „Plješevica“

Figure 2 The existing network of forest truck roads in GJ "Plješevica"

\subsection{Izbor područja pogodnih za gradnju šumskih kamionskih puteva Defining areas suitable for forest roads construction}

Prilikom definisanja područja koja su pogodna za gradnju šumskih kamionskih puteva rukovodili smo se slijedećim:

- za gradnju šumskih kamionskih puteva potrebno je izdvojiti velika finansijska sredstva koja trebaju imati svoje ekonomsko opravdanje,

- područja gdje će se graditi šumski kamionski putevi trebaju se birati tako da se postojeći ekosistem što više sačuva,

- područja gdje će se graditi šumski kamionski putevi moraju pružiti mogućnost razvijanja trase puta koja će ispuniti minimalne tehničke zahtjeve koji se od konkretnog puta očekuju.

Analizom je proizvodni potencijal staništa uzet kao mjerodavan za definisanje područja koja treba otvarati, a ne trenutno stanje u šumi, jer trenutni sastav i struktura pojedinih sastojina često ne ukazuje na njihovu potencijalnu - dugoročnu proizvodnost. Prilikom analize isplativosti izgradnje pojedinih dionica šumskih puteva, mora se uzeti u obzir mnogo duži vremenski period od jednog uređajnog perioda. Sa tim u vezi potrebno je analizirati i dugoročne prihode koji će se moći ostvariti iz pojedinih sastojina. U tom cilju, u radu je definisan teoretski model šume sa normalnom zalihom koji upućuje na te prihode. 
Za gradnju šumskih kamionskih puteva treba birati područja gdje će gradnja s obzirom na obim zemljanih radova, kao i s obzirom na troškove gradnje uvjetovane kategorijom terena, zahtijevati najmanje finansijskih sredstava.

O prethodno navedenim aspektima vodilo se računa tako što su se kreirale slijedeće tematske karte:

- tematska karta: normalna zaliha,

- tematska karta: nagib terena,

- tematska karta: dubina zemljišta.

\subsubsection{Tematska karta - normalna zaliha Thematic map: Normal growing stock}

Za područje BiH,u okviru šuma bukve i mješovitih šuma bukve i jele te bukve i jele sa smrčom ĆIRIć, STEFANOvić i DRINIĆ (1971) opisali su i izdvojili osnovne i proizvodne tipove šuma. STEFANOVIĆ, V. et al (1977) je izdvojio i opisao tipove šuma hrasta kitnjaka u Bosni i Hercegovini. Autori su takođe preporučili optimalni sastav vrsta drveća za pojedine proizvodne tipove šuma i način gazdovanja u budućnosti. Na temelju ovih preporuka izračunati su normalni sastavi pojedinih šuma za „Unsko“ šumskogospodarsko područje a time i za šume u GJ „Plješevica“.

Za potrebe realizacije zadatka ovog rada, normalni sastavi šuma na području GJ „Plješevica“" su formirani tako da je:

- pretpostavljeno da su sve goleti, izdanačke šume prevedene u visoke šume, i to prema pripadnosti pojedinim tipovima šuma.

- subalpinske šume zauzimaju površine na visokim nadmorskim visinama u prosjeku oko $1400 \mathrm{~m}$, sa inklinacijom terena $20^{\circ}$. Ove šume nemaju proizvodni već zaštitni karakter. Sa tim u vezi je za njih kao „normalna zaliha“ uzeta zaliha manja od 100 $\mathrm{m}^{3} /$ ha, tj. ona koja neće imati značajan uticaj na izbor trasa puteva.

Unutar GJ „Plješevica“, prisutne su šume koje se prema normalnoj veličini zalihe jako razlikuju. Prostorni položaj sastojina koje, prema svom normalnom stanju imaju veće zalihe, treba da imaju i veći uticaj prilikom pozicioniranja trasa puteva. Prema tome, bilo je porebno formirati bodovnu skalu koja predstavlja taj uticaj.

Tabela 1. Bodovna skala za normalnu zalihu

Table 1 Point limit for normal growing stock

\begin{tabular}{|c|c|}
\hline $\begin{array}{c}\text { Normalna zaliha } \\
\text { Normal growing stock } \\
\mathrm{m}^{3} / \text { ha }\end{array}$ & $\begin{array}{c}\text { Bodova } \\
\text { Point }\end{array}$ \\
\hline $0-100$ & 0 \\
\hline $101-200$ & 2 \\
\hline $201-300$ & 3 \\
\hline $301-400$ & 4 \\
\hline $401-500$ & 5 \\
\hline
\end{tabular}


Ukoliko se izuzmu područja koja nemaju proizvodnu već zaštitnu funkciju pa se njihova normalna zaliha nije utvrđivala tj. uzeta je $<100 \mathrm{~m}^{3} /$ ha (subalpinske šume), najmanju normalnu zalihu imaju šume crnog graba i crnog jasena ( ili bez crnog jasena) na rendzinama na kristalastom dolomitu, od $107 \mathrm{~m}^{3} / \mathrm{ha}$, koje u radu imaju značaj od 2 boda. Najvišu normalnu zalihu imaju šume bukve i jele na ilimerizovanim zemljištima na krečnjaku sa normalnom zalihom $438 \mathrm{~m}^{3} / \mathrm{ha}$, i prema tome imaju značaj od 5 bodova. Najrasprostranjenije su šumame bukve i crnog graba (šume bukve sa gluhačem) na crnicama i plitkim smeđim zemljištima na jedrom krečnjaku koje imaju normalnu zalihu $256 \mathrm{~m}^{3} /$ ha, i zauzimaju površinu od 969,23 ha Najmanju površinu zauzimaju šume kitnjaka i običnog graba na rendzinama na kristalastom dolomitu koje imaju normalnu zalihu $188 \mathrm{~m}^{3} / \mathrm{ha}$.

Za ostvarivanje racionalnog gazdovanja potrebno je šumu otvoriti odgovarajućom mrežom šumskih saobraćajnica. Mreža šumskih saobraćajnica treba da omogući primjenu mehanizacije u svim fazama gazdovanja šumama, za potrebe korištenja, uzgoja, zaštite šuma, kao i mehanizacije za prevoz šumskih sortimenata. Pri tome treba imati na umu da putevi pored osnovne funkcije i namjene za potrebe šumarstva imaju značajnu funkciju i za druge korisnike (lov, turizam, poljoprivreda, itd.).

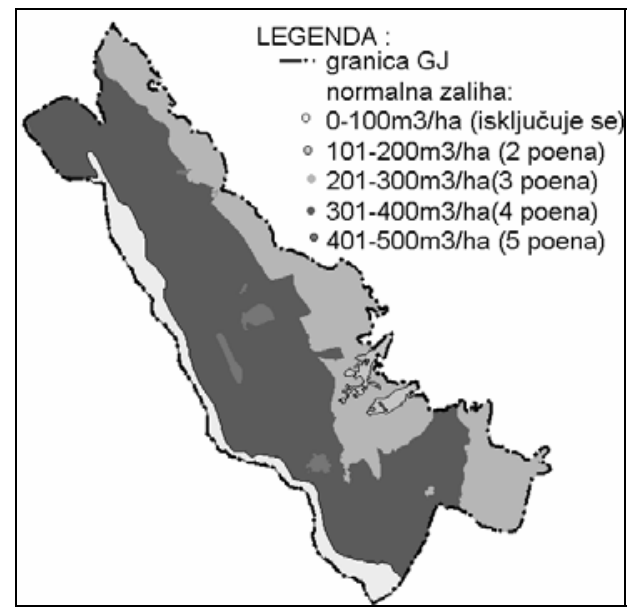

Slika 3. Tematska karta: Normalna zaliha Figure 3. Thematic map: Normal growing stock

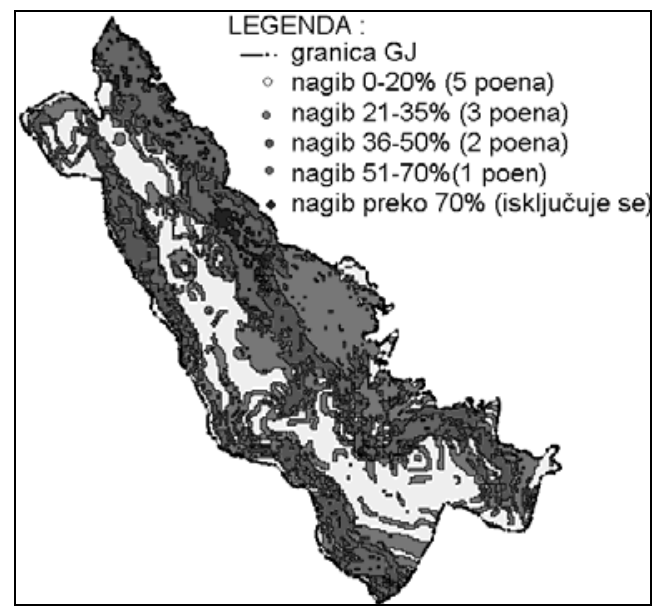

Slika 4. Tematska karta: Nagib terena Figure 4. Thematic map: Slope of the terain

Pretpostavka je da se analiziranim šumskim područjem gazduje na naučnim osnovama u cilju kontinuiranog dobijanja visokih prinosa. S obzirom da se pretpostavlja da je biološki aspekt u gazdovanju šumama stabilna veličina, moguće je da i tehnička komponenta (misli se na šumske kamionske puteve) u gazdovanju šumama bude postojana veličina. 


\subsubsection{Tematska karta - nagib terena \\ Thematic map: Slope of the terain}

Prema smjernicama za projektovanje i građenje šumskih kamionskih puteva, maksimalni uzdužni nagib puteva ne treba prelaziti $7 \%$. Razlozi za ograničenje uzdužnog nagiba su:

- tehničke karakteristike vozila koja prevoze drvne sortimente (sporija vožnja u usponu, otežano kočenje na strmijim nagibima u padu, itd.),

- na nagibima puta većim od $7 \%$ radi erozionog djelovanja kišnice dolazi do brzog ispiranja i propadanja kolovoza.

$\mathrm{Na}$ terenima blažih poprečnih nagiba moguće je relativno kratkom dužinom puta savladati određenu visinsku razliku, te tako povezati dvije tačke putem za čiju gradnju nisu potrebna velika finansijska sredstava. Na strmijim terenima postoji opasnost da škarpa nasipa sklizne niz strmi teren. Zbog toga je potrebno ili graditi skupe potporne zidove (što se izbjegava na ŠKP) ili sa planumom puta ići u samonikli teren povećavajući time količinu viška otkopa koji se najčešće bočno prebacuje ispod puta na obraslu šumsku površinu i na taj način nanosi šteta stablima ispod puta. Ovo su osnovni razlozi zbog kojih je za planiranje mreže šumskih puteva potrebno utvrditi poprečni nagib terena. Nagib terena se dobio pomoću softvera Progis Isomodul.

Ulazni podaci za ovaj softver su $\mathrm{x}, \mathrm{y}, \mathrm{i} z$ koordinate istraživanog područja. $\mathrm{Za}$ područje GJ „Plješevica“ izabrano je 7500 tačaka za koje su očitane x, y i z koordinate koje su unesene u računar i obrađene pomoću navedenog softvera. Zadata je površina 50 x 50 m kao elementarna površina tačnosti zadatih informacija.

Za bodovanje nagiba terena uzela se klasifikacija prema PENTEKU (2002):

Tabela 2. Bodovna skala za nagib terena

Table 2 Point limit for slope of the terain

\begin{tabular}{|c|c|}
\hline $\begin{array}{c}\text { Nagib terena } \\
\text { Slope of the terain } \\
\%\end{array}$ & $\begin{array}{c}\text { Bodova } \\
\text { Point }\end{array}$ \\
\hline $0-20$ & 5 \\
\hline $21-35 \%$ & 3 \\
\hline $36-50 \%$ & 2 \\
\hline $51-70 \%$ & 1 \\
\hline preko $71 \%$ & isključuje se \\
\hline
\end{tabular}




\subsubsection{Tematska karta - dubina zemljišta Thematic map: Depth of the soil}

Zemljani radovi, odnosno gradnja donjeg stroja šumskog kamionskog puta učestvuju u cijeni izgradnje sa cca 30 do $70 \%$, ovisno o obimu zemljanih radova po dužnom metru puta i o građevinskoj kategoriji terena u kojoj se put gradi. Prema građevinskim normama (GN-200) zemljišta su razvrstana u sedam kategorija $\mathrm{s}$ obzirom na otpor koji pružaju pri iskopu. Zemljišta I do IV kategorije kopaju se bez primjene eksploziva, a od V do VII kategorije uz primjenu eksploziva - tabela 3.

Tabela 3. Kategorije i karakteristike zemljišta, JELIČıć (1983.)

Table 3 Categories and features of the soil, JELIČIĆ (1983.)

\begin{tabular}{|l|l|l|}
\hline $\begin{array}{l}\text { Kategorija } \\
\text { Category }\end{array}$ & $\begin{array}{l}\text { Zemljište } \\
\text { Soil }\end{array}$ & $\begin{array}{l}\text { Sredstva za } \\
\text { otkopavanje } \\
\text { Devices for digging }\end{array}$ \\
\hline & ZEMLJA & \\
\hline I & Rastresita & Lopata \\
\hline II & Obična & Ašov \\
\hline III & Čvrsta & Kramp \\
\hline & STIJENA & \\
\hline IV & Trošna & Kramp i ćuskija \\
\hline V & Meka & Barut \\
\hline VI & Čvrsta & Eksploziv \\
\hline VII & Vrlo čvrsta & Eksploziv \\
\hline
\end{tabular}

Kategorije terena ulaze u predračun troškova gradnje šumskih kamionskih puteva na osnovu odgovarajućeg broja probnih profila duž trase puta. Konačna kategorizacija terena može se izvršiti tek nakon završetka gradnje puta. Kategorija terena ima najveći uticaj na troškove zemljanih radova u gradnji šumskih kamionskih puteva. Ipak, veliki je uticaj i dubine zemljišta na obim zemljanih radova a time i na troškove gradnje šumskih kamionskih puteva. To je naročito važno kad se dubina zemljišta posmatra u kombinaciji sa poprečnim nagibom terena. Tako, plitka zemljišta na terenima blažih poprečnih nagiba predstavljaju tla gdje je najjeftinije graditi put $\mathrm{s}$ obzirom na troškove donjeg i gornjeg stroja. Međutim, ako se radi o istoj vrsti zemljišta ali na nekom strmijem terenu, gdje se radi ispunjavanja osnovnih tehničkih zahtjeva mora sa niveletom puta ići dublje u samonikli teren, ispod površine plitkog zemljišta naići će se na matičnu stijenu. Troškovi zemljanih radova u tom slučaju zavisit će od stepena razgradnje matične stijene i u svakom slučaju biti će dosta visoki. Na dubljim zemljištima, čak ako su u pitanju i strmiji poprečni nagibi terena, potrebni su manji troškovi za zemljane radove nego na plitkim zemljištima.

Dubina pojedinih vrsta zemljišta je uzeta iz pedološkog tumača urađenog za ovo područje. Bodovanje mozaika zemljišta je urađeno prema procentualnoj 
zastupljenosti pojedinih tipova zemljišta. Tematska karta - dubina zemljišta je data na slici 5, a bodovala se prema granicama datim u tabeli 4.

Tabela 4 Bodovna skala za dubinu zemljišta

Table 4 Point limit for depth of the soil

\begin{tabular}{|c|c|}
\hline $\begin{array}{c}\text { Dubina zemljišta } \\
\text { Depth of the soil } \\
\text { cm }\end{array}$ & $\begin{array}{c}\text { Bodova } \\
\text { Point }\end{array}$ \\
\hline $0-30$ & 1 \\
\hline $31-40 \%$ & 2 \\
\hline $41-50 \%$ & 3 \\
\hline $51-80 \%$ & 4 \\
\hline preko $81 \%$ & 5 \\
\hline
\end{tabular}

Slika 5. Tematska karta - dubina zemljišta Figure 5 Thematic map: Depth of the soil

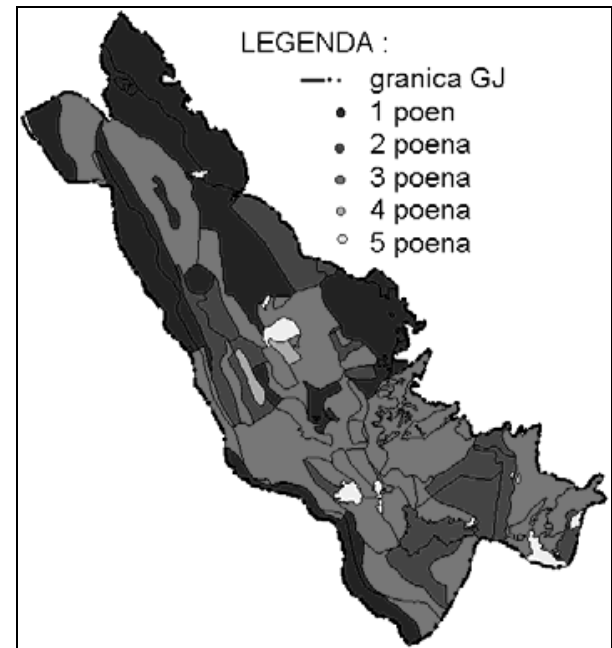

\section{Izdvajanje područja pogodnih za gradnju šumskih kamionskih puteva Marking areas suitable for forest roads construction}

Preklapanjem tematskih karata $\mathrm{i}$ to: normalna zaliha, nagib terena $\mathrm{i}$ dubina zemljišta, grafički i matematički dobila su se područja koja su s obzirom na zajednički uticaj analiziranih faktora više ili manje pogodna za gradnju šumskih kamionskih puteva.

Na slici 6 je data zbirna tematska karta koja predstavlja sumu navedene tri tematske karte. Na ovoj slici uočavaju se područja sa ukupnim brojem poena od 0 do maksimalno 15 poena. Područja koja nose 0 poena su u startu isključena jer se radi o subalpinskim šumama koje nemaju proizvodni već zaštitni karakter, ili o terenima nagiba preko $71 \%$ na kojima bi troškovi gradnje puteva bili veoma visoki, i zato što bi se šumi oduzeo veliki dio produktivne površine.

Ostale površine nose minimalno 5 do maksimalno 15 poena.

Utvrđeno je da se područja koja nose od 0 do 6 poena isključe iz zona pogodnih za gradnju šumskih kamionskih puteva. Ukupna površina područja koja se neće otvarati je 1402 ha. Dakle, područja koja nose od minimalno 7 do maksimalno 15 poena su zone pogodne za gradnju šumskih kamionskih puteva i zauzimaju ukupnu površinu od 4451,2 ha. Na slici 7 data je karta sa definisanim područjima pogodnim za gradnju šumskih kamionskih puteva, odnosno sa definisanim područjima koja nisu pogodna za gradnju. 


\section{Zaključci - Conclusion}

Planovi otvaranja šuma treba da obuhvate i analiziraju tri osnovne grupe faktora: ekonomske, biološke i tehničke. Kad se govori o ekonomskom faktoru u otvaranju šuma misli se da se sa što manjim troškovima koji se ulože u gradnju šumskih kamionskih puteva dobiju što bolji rezultati u otvaranju šuma tj. da se sredstva uložena u gradnju šumskih kamionskih puteva opravdaju preko nižih troškova privlačenja. Biološki faktor se ogleda u vođenju brige da izgrađeni šumski kamionski put što manje naruši postojeći ekosistem. Kroz analizu tehničkog faktora nudi se takvo rješenje trase šumskog kamionskog puta kojim će biti omogućena primjena cjelokupne mehanizacije potrebane $\mathrm{u}$ konkretnom slučaju za gazdovanje šumom.

U ovom radu analizirano je i definisano područje šume koje je pogodno za gradnju šumskih kamionskih puteva. Pri tome je uvažen $i$ analiziran svaki od pomenutih faktora. Ekonomski - kreiranjem tematske karte - normalana zaliha, jer gradnju šumskih kamionskih puteva treba usmjeriti prema onim područjima gdje proizvodni potencijal staništa obećava dobre finansijske rezultate u gazdovanju; biološki i tehnički - kreiranjem tematskih karata - nagib terena i dubina zemljišta, jer gradnja šumskih kamionskih puteva na blažima nagibima terena nanosi najmanje štete u šumi i omogućava tehnički najbolja rješenja.

Slika 6. Izbor bodovne granice-područja pogodna za gradnju ŠKP Figure 6 Selection point range - areas suitable for contruction forest roads

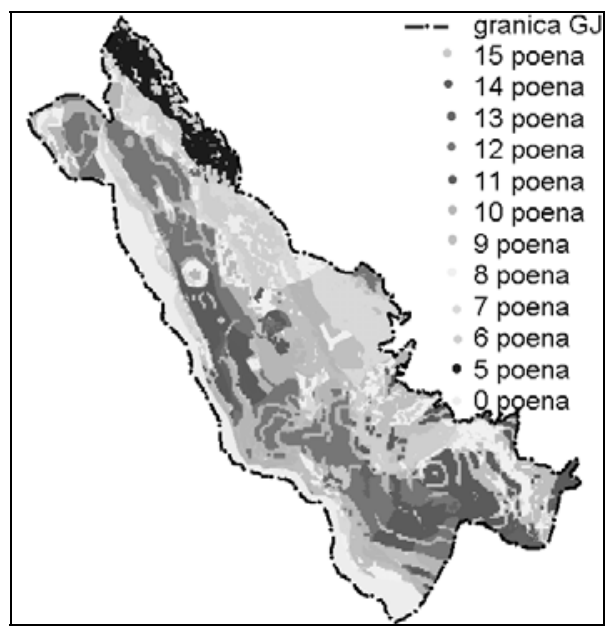

Slika 7. Područja pogodna za gradnju ŠKP igure 7 Areas suitable for constructions forest road

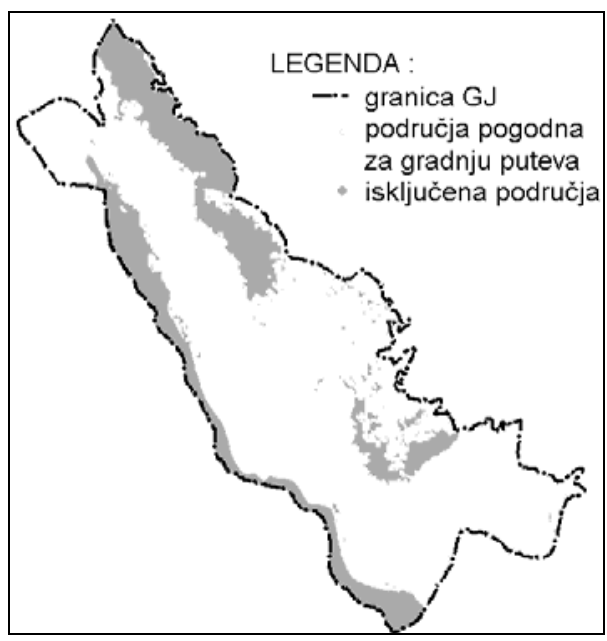

Područja koja su pogodna za radnju šumskih kamionskih puteva na analiziranom šumskom području zauzimaju površinu od 4451,2 ha i na zbirnoj tematskoj karti označena su istom bojom. 


\section{Literatura - References}

ARUGa, K., TASAKA T., Sessions, J., \& MiYATA E.S. 2006.: Tabu serch optimization of forest road alignments combined with shortest paths and cubic splines. Croatian Journal of Forest Engineering. Vol. 27 No. 1, Zagreb, str. 37-47.

ĆIRIĆ, M., STEFANović, V., I DRINIĆ, P. 1971: Tipovi bukovih šuma i mješovitih šuma bukve, jele i smrče u Bosni i Hercegovini, Šumarski fakultet, Sarajevo

ERdas, O., Acar, H., Karaman, A., \& Gümüs, S. 1997: Selecting of Forest Road Routeson the Mountainous Areas Using Geographical Information Systems, XI. World Forestry Congress, Antalya, Turkey, Vol. 3, p. 214-220.

JELIČIĆ, V. 1969: Ekonomski aspekti optimalne strukture mreže šumskih komunikacija u uslovima mehanizacije radova u gospodarskoj jedinici Staretina-Golija-ŠIP "Šator", Glamoč

JELIČIĆ, V. 1983: Šumske ceste i putevi, SIZ odgoja i usmjerenog obrazovanja šumarstva i drvne industrije SRH, Zagreb, str 1-193.

KLEMENČIĆ, I. 1939: Optimalna gustoća šumskih prometala, ŠIPAD, Sarajevo

KRČ, J. 1995: Model napovedovanja oblika spravila lesa, Magistrsko delo, Ljubljana, Biotehniška fakulteta, Oddelek za gozdarstvo, str. 1-115.

PENTEK, T. 2002: Računalni modeli optimizacije mreže šumskih cesta $\mathrm{s}$ obzirom na dominantne utjecajne čimbenike, Disertacija, Šumarski fakultet, Zagreb

PIČMAN, D., 1993: Utjecaj konfiguracije terena i hidrografskih prilika na ekonomsku opravdanost izgradnje optimalne mreže šumskih prometnica, Disertacija, Šumarski fakultet, Zagreb

SHIBA, M. 1992: Optimization of road layout in opening of forest. Proceedings JUFRO Workshop on Computer Supported Planing of Roads and Harvesting, Feldafing, Germany

ŠIKIĆ, D., BABIĆ, B., at all 1989: Tehnički uvjeti za gospodarske ceste, Znanstveni savjet za promet JAZU, Zagreb

TAN, J. 1992: Planning a forest road network by a spatial data handling-network routing sistem, Acta Forestalia Fennica. 1992, No. 227, p. 1 - 85.

\section{Summary - Sažetak}

The analysis which has been done in this paper has the objective to give guidelines for forest opening by defining areas which has to be opened or not. The selection of areas suitable for forest truck roads construction has been done by 
creating three thematic maps in GIS environment as follows normal stock, terrain slope and depth of soil. On each thematic map the evaluation by points has been done on the basis of their impact on decreasing and justifying costs of forest truck roads constructions and impact on decreasing negative consequences of forest roads constructions on existing ecological system. Thematic map of normal stock has been created in order to focus forest opening towards areas where production potential of area is good so positive finial results of forest opening can be expected. Thematic map of terrain slope and depth of soil have been created in order to focus forest opening towards terrains where construction of forest truck road will be the cheapest and cause the lowest damages on existing ecological system.

By overlapping these three maps spatially and by points it has been got aggregate thematic map with total points on each spatial unit. After analysis it has been decided that areas with total units from 7 to 15 are suitable for forest roads constructions taking into consideration specified aspects. These areas have been colored by the same co lour on the aggregate thematic map. Areas which have from zero to six points on aggregate thematic map have been colored by other co lour and these areas are not suitable for construction of forest truck roads network. 